\title{
Calcium and IP3 dynamics in cardiac myocytes: experimental and computational perspectives and approaches
}

\section{Felix Hohendanner ${ }^{1}$, Andrew D. McCulloch ${ }^{2}$, Lothar A. Blatter ${ }^{1}$ and Anushka P. Michailova ${ }^{2 *}$}

1 Department of Molecular Biophysics and Physiology, Rush University Medical Center, Chicago, IL, USA

${ }^{2}$ Department of Bioengineering, University of California San Diego, La Jolla, CA, USA

\section{Edited by:}

Donald M. Bers, University of California, Davis, USA

Reviewed by:

Baruch Minke, The Hebrew

University, Israel

Clemens Möller,

Albstadt-Sigmaringen University, Germany

*Correspondence:

Anushka P. Michailova, Department of Bioengineering, University of California San Diego, 9500 Gilman Drive, La Jolla, CA 92093-0412, USA e-mail: amihaylova@eng.ucsd.edu
Calcium plays a crucial role in excitation-contraction coupling (ECC), but it is also a pivotal second messenger activating $\mathrm{Ca}^{2+}$-dependent transcription factors in a process termed excitation-transcription coupling (ETC). Evidence accumulated over the past decade indicates a pivotal role of inositol 1,4,5-trisphosphate receptor ( $\left(\mathrm{P}_{3} \mathrm{R}\right)$-mediated $\mathrm{Ca}^{2+}$ release in the regulation of cytosolic and nuclear $\mathrm{Ca}^{2+}$ signals. $\mathrm{IP}_{3}$ is generated by stimulation of plasma membrane receptors that couple to phospholipase $C$ (PLC), liberating $\mathrm{IP}_{3}$ from phosphatidylinositol 4,5-bisphosphate $\left(\mathrm{PIP}_{2}\right)$. An intriguing aspect of $I P_{3}$ signaling is the presence of the entire $\mathrm{PIP}_{2}-\mathrm{PLC}-\mathrm{IP} \mathrm{P}_{3}$ signaling cascade as well as the presence of $I P_{3} R s$ at the inner and outer membranes of the nuclear envelope (NE) which functions as a $\mathrm{Ca}^{2+}$ store. The observation that the nucleus is surrounded by its own putative $\mathrm{Ca}^{2+}$ store raises the possibility that nuclear $\mathrm{IP}_{3}$-dependent $\mathrm{Ca}^{2+}$ release plays a critical role in ETC. This provides a potential mechanism of regulation that acts locally and autonomously from the global cytosolic $\mathrm{Ca}^{2+}$ signal underlying ECC. Moreover, there is evidence that: (i) the sarcoplasmic reticulum (SR) and NE are a single contiguous $\mathrm{Ca}^{2+}$ store; (ii) the nuclear pore complex is the major gateway for $\mathrm{Ca}^{2+}$ and macromolecules to pass between the cytosol and the nucleoplasm; (iii) the inner membrane of the $\mathrm{NE}$ hosts key $\mathrm{Ca}^{2+}$ handling proteins including the $\mathrm{Na}^{+} / \mathrm{Ca}^{2+}$ exchanger (NCX)/GM1 complex, ryanodine receptors (RyRs), nicotinic acid adenine dinucleotide phosphate receptors (NAADPRs), $\mathrm{Na}^{+} / \mathrm{K}^{+}$ATPase, and $\mathrm{Na}^{+} / \mathrm{H}^{+}$exchanger. Thus, it appears that the nucleus represents a $\mathrm{Ca}^{2+}$ signaling domain equipped with its own ion channels and transporters that allow for complex local $\mathrm{Ca}^{2+}$ signals. Many experimental and modeling approaches have been used for the study of intracellular $\mathrm{Ca}^{2+}$ signaling but the key to the understanding of the dual role of $\mathrm{Ca}^{2+}$ mediating ECC and ECT lays in quantitative differences of local $\left[\mathrm{Ca}^{2+}\right]$ in the nuclear and cytosolic compartment. In this review, we discuss the state of knowledge regarding the origin and the physiological implications of nuclear $\mathrm{Ca}^{2+}$ transients in different cardiac cell types (adult atrial and ventricular myocytes) as well as experimental and mathematical approaches to study $\mathrm{Ca}^{2+}$ and $\mathrm{IP}_{3}$ signaling in the cytosol and nucleus. In particular, we focus on the concept that highly localized $\mathrm{Ca}^{2+}$ signals are required to translocate and activate $\mathrm{Ca}^{2+}{ }^{2+}$-dependent transcription factors (e.g., nuclear factor of activated T-cells, NFAT; histone deacetylase, HDAC) through phosphorylation/dephosphorylation processes.

Keywords: $\mathrm{Ca}^{2+}, \mathrm{IP}_{3}$, excitation-contraction coupling, excitation-transcription coupling, cardiomyocyte

Calcium is a pivotal signaling molecule and its intracellular concentration $\left(\left[\mathrm{Ca}^{2+}\right]_{\mathrm{i}}\right)$ is precisely regulated in different subcellular domains. The modulation of $\left[\mathrm{Ca}^{2+}\right]$ is a crucial factor for a variety of physiological functions of living cells. In cardiac myocytes, including ventricular and atrial cells, $\mathrm{Ca}^{2+}$ release through channels located in the sarcoplasmic reticulum (SR) membrane and termed ryanodine receptors (RyRs), is a key event linking membrane depolarization and mechanical activity during excitationcontraction coupling (ECC) (Bers, 2001). The amount of $\mathrm{Ca}^{2+}$ release with each heart beat and by that the force of contraction is also modulated by hormonal action, e.g., by Endothelin I and Angiotensin II (Proven et al., 2006). These two hormones stimulate plasma membrane receptors ( $G$ protein coupled receptors, GPCRs) that couple to phospholipase C (PLC), liberating $\mathrm{IP}_{3}$ from phosphatidylinositol 4,5-bisphosphate $\left(\mathrm{PIP}_{2}\right) . \mathrm{IP}_{3}$ freely diffuses within the cytoplasm to bind to a second type of SR $\mathrm{Ca}^{2+}$ release channels, the inositol 1,4,5-trisphosphate receptor $\left(\mathrm{IP}_{3} \mathrm{R}\right)$ (Roderick and Bootman, 2003; Kockskämper et al., 2008; Berridge, 2009). IP ${ }_{3}$ Rs, albeit at a much smaller density compared to ryanodine receptors (RyR:IP $\left.{ }_{3} \mathrm{R} \sim 100: 1\right)$, are expressed 
in the SR membrane and nuclear envelope (NE) (Bootman et al., 2009). The activation of $\mathrm{IP}_{3} \mathrm{Rs}$ upon binding of $\mathrm{IP}_{3}$ can modulate ECC by sensitizing nearby RyRs leading to positive inotropic but also pro-arrhythmic effects (Petersen et al., 1994; Vogelsand et al., 1994; Zima and Blatter, 2004; Harzheim et al., 2009). Experimental evidence accumulated over the past decade also indicates an important role of $\mathrm{IP}_{3} \mathrm{R}$-mediated $\mathrm{Ca}^{2+}$ release in excitation-transcription coupling (ETC) and pro-hypertrophic signaling (Arantes et al., 2012). The entire $\mathrm{PIP}_{2}$-PLC-IP 3 cascade, including GPCRs and $\mathrm{IP}_{3} \mathrm{Rs}$, can be found in the NE (Bkaily et al., 2011; Vaniotis et al., 2011; Tadevosyan et al., 2012). The presence of nuclear GPCRs in combination with highly localized nuclear $\mathrm{IP}_{3} \mathrm{R}$-mediated $\mathrm{Ca}^{2+}$ release and $\mathrm{Ca}^{2+}$ removal might provide for a putative distinct signaling domain that regulates nuclear $\mathrm{Ca}^{2+}$ dynamics (e.g., for autocrine signaling), whereas the cytosolic $\mathrm{Ca}^{2+}$ is regulated separately via sarcolemmal GPCR signaling and $\mathrm{IP}_{3} \mathrm{R}$-mediated $\mathrm{SR} \mathrm{Ca}{ }^{2+}$ release in conjunction with $\mathrm{Ca}^{2+}$ release and removal by the set of proteins involved in ECC (e.g., RyR, SERCA, troponin C). Sarcolemmal GPCRs allow for paracrine signaling and positive inotropic effects mediated by hormonal stimulation (e.g., with Angiotensin II or Endothelin I), (Kockskämper et al., 2008; Bootman et al., 2009). A comprehensive understanding of the mechanisms regulating nuclear $\mathrm{IP}_{3}$ and $\mathrm{Ca}^{2+}$ signals and the impact of alterations of cytosolic $\mathrm{Ca}^{2+}$ and $\mathrm{IP}_{3}$ signals on nuclear functions requires wellcharacterized experimental approaches, but also whole-cell system mathematical models. In this review, we discuss quantitative aspects of $\mathrm{IP}_{3}$-dependent $\mathrm{Ca}^{2+}$ homeostasis in adult ventricular and atrial myocytes. In particular, we focus on novel modeling and experimental approaches to support the concept that $\mathrm{IP}_{3} \mathrm{R}$ mediated $\mathrm{Ca}^{2+}$-release and the $\mathrm{Ca}^{2+}$ removal machinery in the SR and NE allow for highly localized and independent cellular signaling.

\section{EXCITATION-CONTRACTION COUPLING IN VENTRICULAR AND ATRIAL MYOCYTES AND THE ROLE OF IP 3}

In cardiomyocytes, ECC describes the process of action potential (AP) triggered $\mathrm{Ca}^{2+}$-induced $\mathrm{Ca}^{2+}$ release (CICR) providing sufficient $\mathrm{Ca}^{2+}$ for the activation of the proteins regulating muscle contraction and to induce active muscle force (Bers, 2001). Membrane depolarization during an AP allows $\mathrm{Ca}^{2+}$ influx through voltage-dependent L-type $\mathrm{Ca}^{2+}$ channels (LTCC) which triggers CICR and thereby amplifies the cytosolic $\mathrm{Ca}^{2+}$ signal to levels required for the activation of the contractile proteins. An important feature of all ventricular myocytes, setting them apart from most atrial cells, is the presence of plasma membrane invaginations throughout the cytosol (transverse or t-tubules), putting LTCC in close vicinity to RyRs (Figure 1). The SR containing RyRs that oppose LTCC is called junctional SR (jSR). The jSR is crucial for the spatiotemporal homogeneity of $\mathrm{Ca}^{2+}$ release leading to largely uniform cytosolic $\mathrm{Ca}^{2+}$ transients $\left(\left[\mathrm{Ca}^{2+}\right]_{\mathrm{i}}\right)$ during a ventricular cell twitch (Figure 2), (Franzini-Armstrong et al., 1999; Heinzel et al., 2002; Louch et al., 2004; Crossman et al., 2011; Hake et al., 2012; Signore et al., 2013). Unlike in ventricular cells, the t-tubular system in atrial myocytes is either absent (Figure 1) (Hüser et al., 1996; Kockskämper et al., 2001) or poorly developed (Kirk et al., 2003). However more recent work in sheep and human has provided evidence that atrial cells from larger animals tend to have a higher density of t-tubules (Dibb et al., 2009; Richards et al., 2011), and even in rodent atrial cells an irregular internal transverse-axial tubular system has been identified that affects kinetics of SR $\mathrm{Ca}^{2+}$ release (Kirk et al., 2003).The absence or paucity of t-tubules in atrial cells leads to great differences in the shape and kinetics of local $\mathrm{Ca}^{2+}$ transients and gradients in subcellular regions where $\mathrm{Ca}^{2+}$ is provided by release from jSR and non-junctional SR (njSR) (Figure 2). Subsarcolemmal $\mathrm{Ca}^{2+}$ transients rise faster, have a higher $\mathrm{Ca}^{2+}$ peak and are initiated by $\mathrm{Ca}^{2+}$ currents through LTCCs, followed by RyR-mediated $\mathrm{Ca}^{2+}$ release from the jSR. These local jSR $\mathrm{Ca}^{2+}$ transients resemble $\mathrm{Ca}^{2+}$ release in ventricular cells. Central cytosolic $\mathrm{Ca}^{2+}$ transients, however, have a slower rise time and a lower peak, and result from CICR that propagates in a $\mathrm{Ca}^{2+}$ wave-like fashion from the periphery to the center of the cell. (Blatter et al., 2003; Maxwell and Blatter, 2012). Furthermore, the specific topological organization of the plasma membrane in atrial myocytes leads not only to different spatial $\left[\mathrm{Ca}^{2+}\right]_{\mathrm{i}}$ distribution as compared to the ventricle, it also affects nuclear $\mathrm{Ca}^{2+}$ transients by further delaying their onset due to the wave-like propagation of $\mathrm{Ca}^{2+}$ toward the nucleus (Figure 2). Interestingly, for both atrial and ventricular cells, a role of cytosolic $\mathrm{IP}_{3}\left(\left[\mathrm{IP}_{3}\right]_{\mathrm{i}}\right)$ has been reported for the modulation of cytosolic $\mathrm{Ca}^{2+}$ transients in a variety of animal models (Zima and Blatter, 2004; Proven et al., 2006; Domeier et al., 2008; Harzheim et al., 2009; Kim et al., 2010). IP 3 R channel activity, with type- $2 \mathrm{IP}_{3} \mathrm{Rs}$ as the most prevalent isoform in cardiac myocytes, depends on $\left[\mathrm{IP}_{3}\right]_{\mathrm{i}}$ and $\left[\mathrm{Ca}^{2+}\right]_{\mathrm{i}}$ (Michell et al., 1981; Domeier et al., 2008; Kockskämper et al., 2008). There is evidence that atrial myocytes express functional $\mathrm{IP}_{3} \mathrm{Rs}$ at higher densities than ventricular myocytes (Figure 1; in ventricular cell the $\mathrm{IP}_{3} \mathrm{Rs}$ are not shown in the junctional space due their relatively low density) (Mackenzie et al., 2004; Zima and Blatter, 2004). As shown in Figure 2, the acute increase in cytosolic $\mathrm{IP}_{3}$, induced by photolytic release of $\mathrm{IP}_{3}$ from a caged $\mathrm{IP}_{3}$ compound, increases cytosolic $\mathrm{Ca}^{2+}$ transient peak amplitudes during field stimulation in atrial cells in contrast to ventricular cells. In ventricular cells only increased expression levels of $\mathrm{IP}_{3} \mathrm{R}$, as it occurs in cardiac hypertrophy, could experimentally be tied to enhanced cytosolic SR Ca ${ }^{2+}$ release (Harzheim et al., 2009). The neurohumoral stimulation with Endothelin I or Angiotensin II, however, has been shown to have similar positive inotropic effects in both ventricular and atrial cells, indicating a role of $\mathrm{IP}_{3}$-mediated $\mathrm{Ca}^{2+}$ release in the enhancement of cytosolic $\mathrm{Ca}^{2+}$ release (Zima and Blatter, 2004).

\section{EXCITATION-TRANSCRIPTION COUPLING IN VENTRICULAR AND ATRIAL MYOCYTES AND THE ROLE OF IP 3}

Nuclear $\mathrm{Ca}^{2+}$ signals however are different with regards to kinetics during action potential induced $\mathrm{Ca}^{2+}$ transients. This can largely be attributed to the fact that the nucleus is surrounded by the nuclear envelope (Kockskämper et al., 2008; Alonso and García-Sancho, 2011), consisting of the outer and inner nuclear membranes and the space between them that is contiguous with the SR (Wu et al., 2006; Shkryl et al., 2012). The nuclear membranes fuse at many locations to form pores (diameter $\sim 100$, length $\sim 50 \mathrm{~nm}$ ) that harbor the nuclear pore complexes (NPCs). 


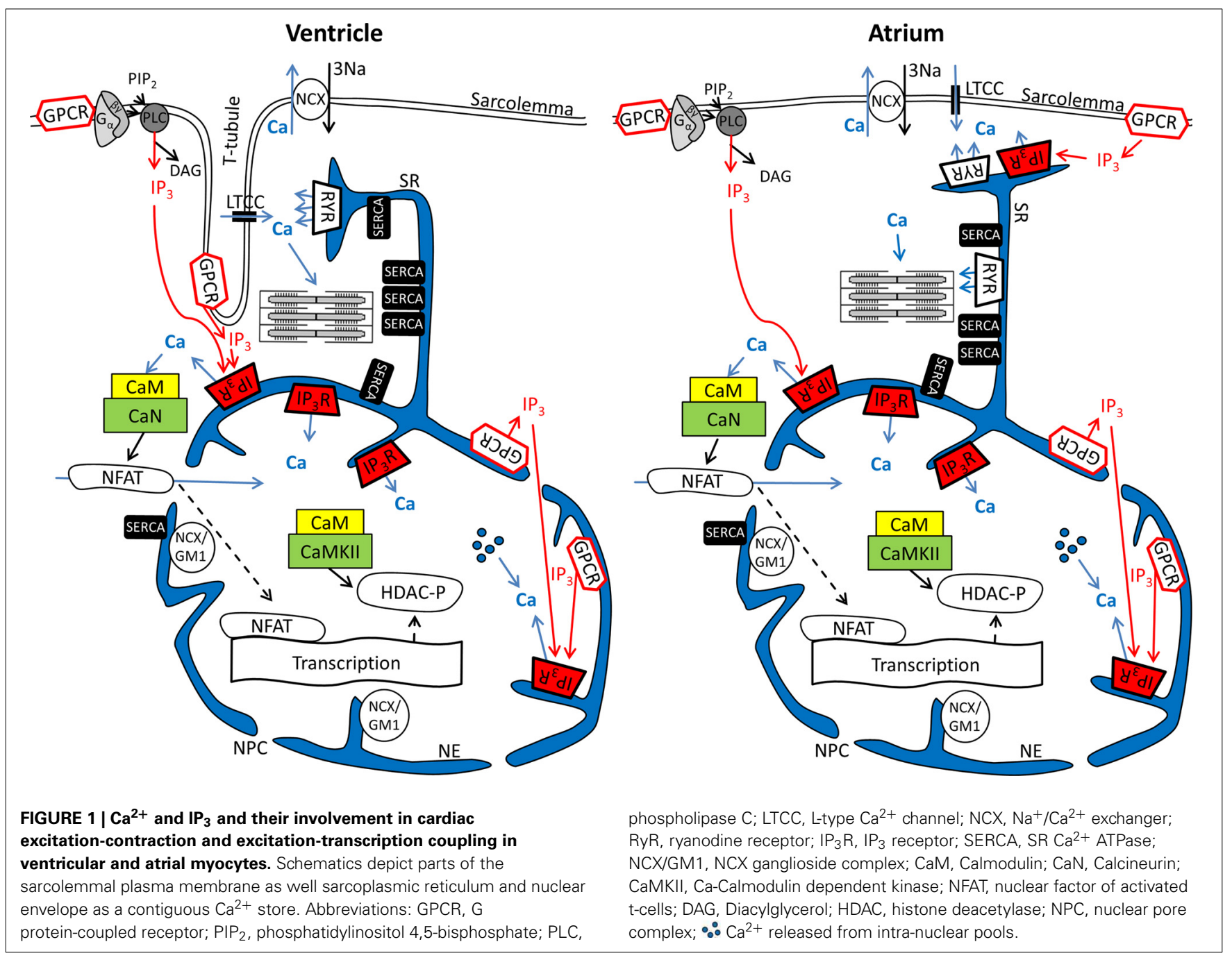

The NPCs are the major gateway for ions (including $\mathrm{Ca}^{2+}$ ) to diffuse along the gradient between the cytosol and nucleoplasm. It has been proposed that NPCs can act as diffusion filter and introduce a kinetic delay in the equilibration of nucleoplasmic $\mathrm{Ca}^{2+}$ concentration $\left(\left[\mathrm{Ca}^{2+}\right]_{\text {nuc }}\right.$ ) and $\left[\mathrm{Ca}^{2+}\right]_{\mathrm{i}}$ (Bootman et al., 2009). The extent of the kinetic delay might be subject to modulation. Although NPCs do not close, their conductance can change in response to factors such as $\mathrm{Ca}^{2+}$ and ATP. The density of NPCs can vary from 1 to 5 NPCs per $\mu \mathrm{m}^{2}$, depending on the cell type (Wang and Clapham, 1999). A greater expression of NPCs would allow for a more rapid equilibration of $\left[\mathrm{Ca}^{2+}\right]_{i}$ and $\left[\mathrm{Ca}^{2+}\right]_{\text {nuc }}$. Recent data from Alonso and García-Sancho (2011) also suggest a role for NE invaginations (nucleoplasmic reticulum) and intra-nuclear $\mathrm{Ca}^{2+}$ pools for the regulation of nuclear $\mathrm{Ca}^{2+}$ (Figure 1). More evidence that nuclear $\mathrm{Ca}^{2+}$ dynamics are not just a function of cytosolic $\mathrm{Ca}^{2+}$ transients can be found in structural and functional differences of $\mathrm{NE} \mathrm{Ca}^{2+}$ handling proteins as compared to the SR. Even though the NE is an extension of the SR (Wu et al., 2006; Shkryl et al., 2012) SERCA presumably is not expressed at the inner NE membrane (Malviya and Klein, 2006; Bootman et al., 2009). Nonetheless, other putative
$\mathrm{Ca}^{2+}$ handling and ion transporting proteins have been suggested to be present in the NE, including a splice variant of the type$1 \mathrm{Na}^{+} / \mathrm{Ca}^{2+}$ exchanger associated with ganglioside (NCX/GM1 complex, typical for non-excitable cells), RyRs, NAADPR (nicotinic acid adenine dinucleotide phosphate receptor), $\mathrm{Na}^{+} / \mathrm{K}^{+}$ ATPase and $\mathrm{Na}^{+} / \mathrm{H}^{+}$exchanger (Gerasimenko et al., 2003; Irvine, 2003; Bkaily et al., 2006; Ledeen and Wu, 2007; Zima et al., 2007; Guatimosim et al., 2008; Wu et al., 2009).

Even more important seems the preferential expression of $\mathrm{IP}_{3} \mathrm{Rs}$ in the NE (Bare et al., 2005). Using Fluo-5N Zima et al. observed a depletion of the nuclear envelope upon experimental stimulation of $\mathrm{IP}_{3}$ Rs with $\mathrm{IP}_{3}$ in isolated nuclei (Zima et al., 2007) that was paralleled by an increase of $\left[\mathrm{Ca}^{2+}\right]_{\text {nuc }}$. Wu and colleagues obtained similar results with Fluo-5N on $\mathrm{IP}_{3}$ dependent NE Ca ${ }^{2+}$ depletion in permeabilized cells (Wu et al., 2006). The importance of $\mathrm{IP}_{3}$ for the regulation of $\left[\mathrm{Ca}^{2+}\right]_{\text {nuc }}$ is underscored by the results shown in Figure 2: Following cell-wide $\mathrm{IP}_{3}$ uncaging, nuclear $\mathrm{Ca}^{2+}$ transients are consistently and preferentially altered in atrial and ventricular cells. However since $\mathrm{IP}_{3}$ is buffered (i.e., by $\mathrm{IP}_{3} \mathrm{Rs}$ ) and degraded over time (Woodcock and Matkovich, 2005), the subcellular localization of $\mathrm{IP}_{3} \mathrm{Rs}$ and the site of $\mathrm{IP}_{3}$ 


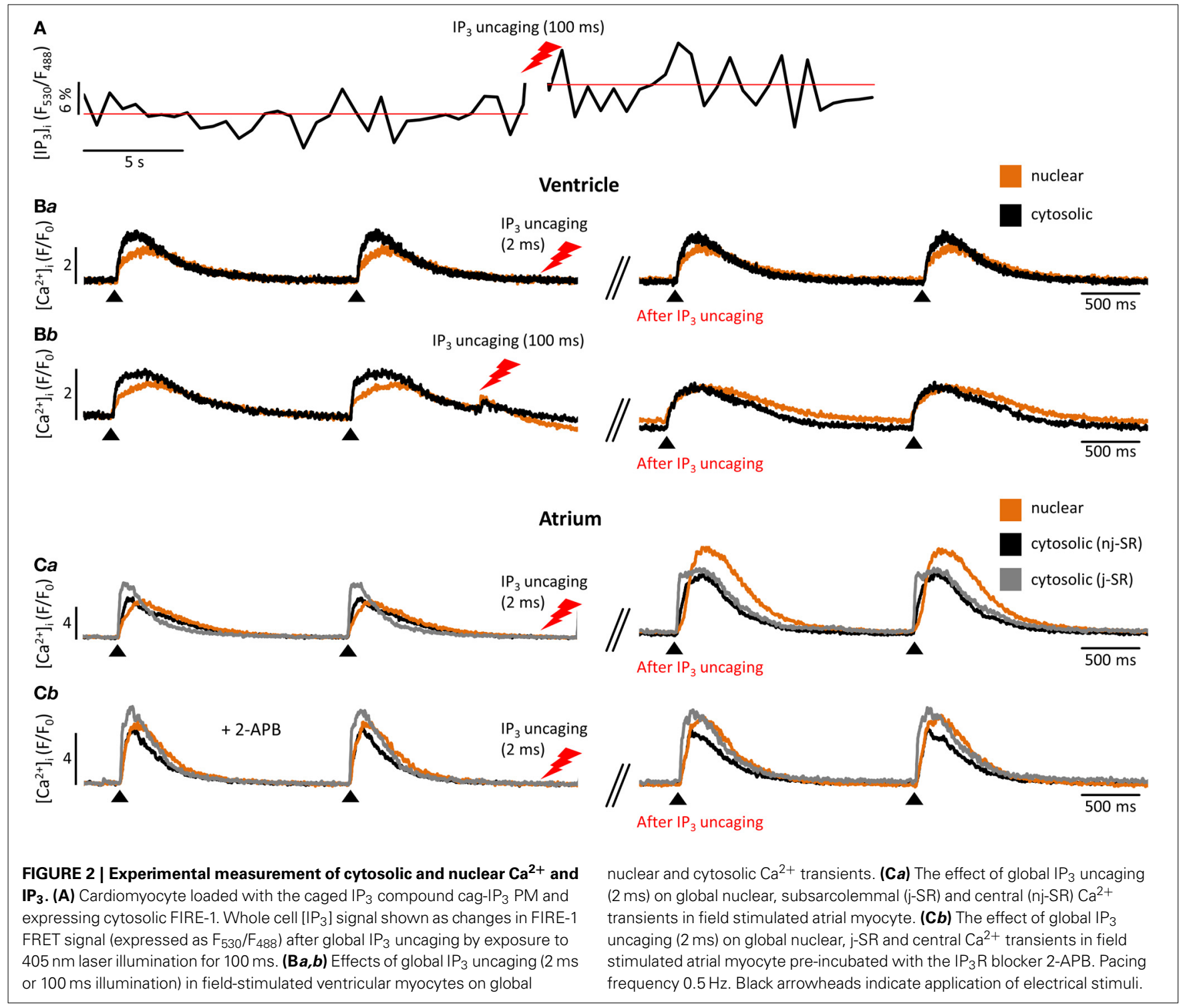

generation (i.e., GPCR) are important to generate highly localized $\mathrm{Ca}^{2+}$ signals to control $\mathrm{Ca}^{2+}$-dependent transcription (Bers, 2013; Ibarra et al., 2013). The traditional view on the positioning of GPCRs in cardiac myocytes sees their main site of expression in the sarcolemmal and nuclear membrane (Figure 1). Only recently, work from Ibarra et al. (2013) suggested a third type of localization for GPCRs in t-tubules close to the nuclear envelope (Figure 1, ventricular cell). The positioning of $\mathrm{IP}_{3}$ production and $\mathrm{IP}_{3} \mathrm{Rs}$ is important since differences in the kinetics of local $\left[\mathrm{Ca}^{2+}\right]$ can lead to altered activation of transcription factors. A pronounced local elevation of $\left[\mathrm{Ca}^{2+}\right]$ for instance, can activate calmodulin dependent-protein kinase II (CaMKII) and promote histone deacetylases (HDAC) phosphorylation (Wu et al., 2006), whereas a sustained smaller $\left[\mathrm{Ca}^{2+}\right]$ elevation increases nuclear factor of activated T-cells (NFAT) dephosphorylation via the $\mathrm{Ca}^{2+}$ sensitive phosphatase calcineurin $(\mathrm{CaN})$. This ultimately leads to the activation of different sets of transcription factors, e.g., myocyte enhancer factor 2 (MEF2) for HDAC and GATA for
NFAT (Molkentin et al., 1998). The separate set of $\mathrm{Ca}^{2+}$ release and removal proteins in the NE, with $\mathrm{IP}_{3} \mathrm{Rs}$ as the most prominent example, as well as the specific expression of GPCRs in the sarcolemmal and nuclear membranes might be key to understanding the conundrum of $\mathrm{Ca}^{2+}$ being a modulator of contraction and transcription at the same time (Bootman et al., 2009). Mathematical modeling of nuclear and cytosolic $\mathrm{Ca}^{2+}$ homeostasis, accounting for different expression levels of sarcolemmal, cytosolic and nuclear $\mathrm{Ca}^{2+}$ handling proteins, paralleled by experimental approaches might provide a better understanding of functional differences of nuclear and cytosolic $\mathrm{Ca}^{2+}$.

\section{EXPERIMENTAL TOOLS FOR MEASURING CYTOSOLIC AND NUCLEAR $\mathrm{Ca}^{2+}$ AND IP 3 SIGNALS}

Confocal laser microscopy, multiphoton imaging and conventional microscopy provide the basis for visualization of whole cell and subcellular ion concentration distributions, and the development of chemical fluorescent $\mathrm{Ca}^{2+}$ indicators 
(Grynkiewicz et al., 1985) made imaging of $\mathrm{Ca}^{2+}$ movements inside living cells feasible. Nowadays a variety of ratiometric and non-ratiometric $\mathrm{Ca}^{2+}$ indicators, with Indo-1 and Fluo-4 among the most prominent examples, are being used. In principle, upon excitation, these indicators emit light at particular wave lengths and the emitted fluorescence intensity or the emission spectrum is changed in a $\mathrm{Ca}^{2+}$ bound state (Takahashi et al., 1999). The dissociation constant $\left(\mathrm{K}_{d}\right)$ as a measure of $\mathrm{Ca}^{2+}$ binding affinity is crucial for the selection of the appropriate $\mathrm{Ca}^{2+}$ dye for a particular cellular compartment of interest. Low affinity, high $\mathrm{K}_{d}$ dyes (like Fluo-5N) are used for the visualization of changes in SR $\left[\mathrm{Ca}^{2+}\right]$ or nuclear envelope $\left[\mathrm{Ca}^{2+}\right]$, whereas, e.g., Fluo- $4\left(\mathrm{~K}_{d}\right.$ of $\left.345 \mathrm{nM}\right)$ is one of the preferred dyes for imaging of changes in cytosolic free $\left[\mathrm{Ca}^{2+}\right]$, which varies roughly between $100 \mathrm{nM}$ and values at times exceeding $1 \mu \mathrm{M}$ during ECC. Since the nucleoplasm and the cytoplasm are interconnected compartments with similar global $\left[\mathrm{Ca}^{2+}\right]$ characteristics, dyes suitable to show changes in $\left[\mathrm{Ca}^{2+}\right]_{\mathrm{i}}$ can be used for the detection of changes in $\left[\mathrm{Ca}^{2+}\right]_{\text {nuc }}$ as well. Using $\mathrm{Ca}^{2+}$ sensitive dyes, Zima and Blatter (2004) were able to visualize cytosolic IP ${ }_{3}$ R-mediated $\mathrm{Ca}^{2+}$ release events $\left(\mathrm{Ca}^{2+}\right.$ puffs) and show a positive inotropic effect of neurohumoral stimulation with Endothelin-1 in cardiac myocytes. As mentioned above, the same group was also able to show changes of local nuclear envelope $\left[\mathrm{Ca}^{2+}\right]$ in isolated nuclei upon stimulation with $\mathrm{IP}_{3}$, using Fluo-5N (Zima et al., 2007).

A variety of pharmacologic interventions can be used to influence the $\mathrm{IP}_{3}$-dependent signaling cascade. Tools for stimulation of the neurohumoral GPCR pathway in cardiomyocytes include for example Angiotensin II and Endothelin-1. PLC-inhibitors like U73122 and $\mathrm{IP}_{3} \mathrm{R}$ blockers like 2-Aminoethoxydiphenyl borate (2-APB) or heparin are widely used $\mathrm{IP}_{3} \mathrm{R}$ blockers to study the GPCR/PLC/IP 3 pathway. More recent molecular techniques and the generation of transgenic animals complement these tools. Noteworthy are the generation of $\mathrm{IP}_{3} \mathrm{R}$ knock-out and $\mathrm{IP}_{3} \mathrm{R}$ overexpressing mice as well as the development of $\mathrm{IP}_{3}$-sponges that allows the cellular overexpression of $\mathrm{IP}_{3}$ buffering proteins. The generation of $\mathrm{IP}_{3} \mathrm{R}$ overexpressing mice combined with the adenoviral expression of an $\mathrm{IP}_{3}$ sponge provided novel insights into the importance of this pathway in cardiac physiology and pathophysiology. $\mathrm{Ca}^{2+}$ transients in $\mathrm{IP}_{3} \mathrm{R}$ overexpressing mice were increased and showed a higher potential for arrhythmias after Endothelin-1 treatment. These effects were abrogated after expression of the $\mathrm{IP}_{3}$ sponge (Nakayama et al., 2010). Insensitivity toward GPCR stimulation and $\mathrm{IP}_{3} \mathrm{R}$-mediated pro-arrhythmic effects were confirmed in $\mathrm{IP}_{3} \mathrm{R}$ knock-out mice (Li et al., 2005).

An approach to directly visualize cellular $\left[\mathrm{IP}_{3}\right]$ would allow for a more complete picture of cell physiology. Only recently Remus et al. (2006) developed biosensors termed FIRE to dynamically study $\left[\mathrm{IP}_{3}\right]$ in living cells. Briefly, FIRE is incorporated into an adenoviral vector, expressed in target cells, and utilizes fluorescence resonance energy transfer (FRET) between cyan and yellow fluorescent protein (CFP and YFP) upon binding of $\mathrm{IP}_{3}$. For that purpose FIRE contains a fusion protein of CFP, YFP, and the $\mathrm{IP}_{3}$ binding domain of the $\mathrm{IP}_{3}$ receptor type 1,2 , or 3 and can be targeted to the cytosolic or nuclear compartment. An increase in $\left[\mathrm{IP}_{3}\right]$ is detected by an increase in FRET signals and a change in the YFP/CFP fluorescence ratio.
Further progress in the study of $\mathrm{IP}_{3}$-dependent $\mathrm{Ca}^{2+}$ signaling became possible with the development of caged $\mathrm{IP}_{3}$ compounds (Smith et al., 2009). Upon UV-light dependent photolysis, $\mathrm{IP}_{3}$ is released in its biological active form and can be readily used to study this signaling pathway without possible additional effects of GPCR stimulation other than $\mathrm{IP}_{3}$ generation (i.e., effects mediated by diacylglycerol that is generated concomitantly with $\mathrm{IP}_{3}$ by PLC). These approaches can be used in parallel, as shown in Figure 2A: a cardiomyocyte expressing FIRE-1-cyt exhibits an increase in the FRET signal of $\sim 6 \%$ upon $\mathrm{IP}_{3}$ uncaging, indicative of a detectable change of global cytosolic $\left[\mathrm{IP}_{3}\right]$. Moreover Figure 2 depicts the influence of $\mathrm{IP}_{3}$ uncaging on different cellular compartments in atrial and ventricular cells. Figure 2B exemplifies the small impact of $\mathrm{IP}_{3}$ uncaging on local cytosolic and nuclear $\mathrm{Ca}^{2+}$ transients in field stimulated $(0.5 \mathrm{~Hz})$ ventricular cells (Fluo-4). Only prolonged exposure to the $\mathrm{IP}_{3}$ uncaging signal $(100 \mathrm{~ms}$ laser illumination) has immediate visible effects on local $\mathrm{Ca}^{2+}$ release (Figure $2 \mathrm{C}$ ). The $\mathrm{IP}_{3}$ effects on diastolic $\left[\mathrm{Ca}^{2+}\right]_{\mathrm{i}}$ and the $\mathrm{Ca}^{2+}$ transient amplitude are particularly pronounced for the nuclear region. As compared to ventricular cells, atrial myocytes are more sensitive to $\mathrm{IP}_{3}$ uncaging at smaller laser exposure durations ( $2 \mathrm{~ms}$; i.e., smaller $\left.\left[\mathrm{IP}_{3}\right]\right)$ and the overall effect on cytosolic, nuclear and subsarcolemmal $\mathrm{Ca}^{2+}$ transient amplitudes is higher upon $\mathrm{IP}_{3}$ uncaging. Note also the altered $\mathrm{Ca}^{2+}$ transient kinetics with a prolongation of the $\mathrm{Ca}^{2+}$ transient's amplitude following $\mathrm{IP}_{3}$ uncaging (Figure $2 \mathrm{Ca}$ ). Figure $2 \mathrm{Cb}$ shows the effect of the $\mathrm{IP}_{3} \mathrm{R}$ blocker 2 -APB $(10 \mu \mathrm{M})$. The effect of $\mathrm{IP}_{3}$ uncaging on $\mathrm{Ca}^{2+}$ transients in an atrial cell, pre-incubated with 2-APB, was abolished.

\section{MATHEMATICAL APPROACHES FOR SIMULATING CYTOSOLIC AND NUCLEAR $\mathrm{Ca}^{2+}$ AND IP ${ }_{3}$ SIGNALS}

Computational modeling has proven to be a powerful approach to study cardiac physiology and its implications for disease. With increasing availability of biophysical and physiological data, mathematical models have also become more sophisticated. They provided new insights into how cellular structures, channels and receptor distributions or $\mathrm{Ca}^{2+} / \mathrm{IP}_{3}$ signaling regulate cardiac ECC. A number of deterministic models of ventricular and atrial myocyte electrophysiology, intracellular $\mathrm{Ca}^{2+}$ handling and bioenergetics have been published. For a more complete review on successes and failures in these modeling pursuits we refer the reader to some excellent recently published articles (Noble, 2011; Jafri, 2012; Noble et al., 2012; Sobie and Lederer, 2012; Poláková and Sobie, 2013; Wilhelms et al., 2013). Several computational models have been constructed to investigate $\mathrm{IP}_{3}$ synthesis and the sub-cellular mechanisms regulating $\mathrm{IP}_{3} \mathrm{R}$-mediated $\mathrm{Ca}^{2+}$ signaling. The first model of an $\mathrm{IP}_{3}$ signaling system, built to simulate $\mathrm{IP}_{3}$ signals in response to stimulation with cardiac hypertrophic neurohumoral agonists like Endothelin-1 and Angiotensin II, was published by Cooling et al. (2007). The key controlling parameters with respect to the resultant cytosolic $\left[\mathrm{IP}_{3}\right]$ in atrial cells were identified, including phosphorylation of membrane receptors, ligand strength, binding kinetics to pre-coupled (with GaGDP) receptors and kinetics associated with pre-coupling the receptors. In 1992, De Young and Keizer (1992) constructed the first simplified model of the $\mathrm{IP}_{3}$ receptor. Subsequent theoretical studies, 
based on new experimental data, have investigated the complex dynamic properties of type 1,2 , or $3 \mathrm{IP}_{3} \mathrm{Rs}$ (Li and Rinzel, 1994; Laurent and Claret, 1997; LeBeau et al., 1999; Moraru et al., 1999; Mak et al., 2001; Sneyd and Dufour, 2002; Dawson et al., 2003; Siekmann et al., 2012). Based on quantitative measurements of $\mathrm{IP}_{3} \mathrm{R}$ properties, several stochastic models of the single channel and channel-clusters have been constructed (Swillens et al., 1998; Shuai and Jung, 2002; Falcke, 2003; Fraiman and Dawson, 2004; Thul and Falcke, 2004; Gin et al., 2009). Fraiman and Dawson (2004) were the first to include an explicit dependence of $\mathrm{IP}_{3} \mathrm{R}$ gating on SR-luminal $\mathrm{Ca}^{2+}$. To investigate the mechanisms underlying pacemaker cell activity, Youm et al. (2006) developed a deterministic model that includes ion channels, NCX, pumps, the intracellular machinery for $\mathrm{Ca}^{2+}$ regulation, cytosolic $\mathrm{IP}_{3}$ production and $\mathrm{IP}_{3}$-mediated $\mathrm{Ca}^{2+}$ release activity. Their model supports the idea that the cyclic changes in cytosolic $\mathrm{Ca}^{2+}$ and $\mathrm{IP}_{3}$ play a key role in the generation of regenerative pacemaker potentials. Spatiotemporal continuum models, seeking to investigate the mechanisms of $\mathrm{IP}_{3}$-mediated $\mathrm{Ca}^{2+}$ signaling in cells where $\mathrm{IP}_{3}$ Rs are known to be the dominant $\mathrm{Ca}^{2+}$ release channels, have been published as well. Jafri and Keizer, combining a realistic model of $\mathrm{IP}_{3}$-induced $\mathrm{Ca}^{2+}$ oscillations with the diffusion of $\mathrm{IP}_{3}$ and buffered diffusion of $\mathrm{Ca}^{2+}$, developed a reaction-diffusion continuum model in Xenopus oocytes (Jafri and Keizer, 1994, 1995). Their results suggest that $\mathrm{Ca}^{2+}$ diffusion, which was much slower than that of $\mathrm{IP}_{3}$ because of endogenous $\mathrm{Ca}^{2+}$ buffers, had only a small effect on predicted $\mathrm{Ca}^{2+}$ transients. These findings imply a possible previous undisclosed role for $\mathrm{IP}_{3}$ in cell signaling. Means et al. (2006) used a reaction-diffusion model to simulate $\mathrm{Ca}^{2+}$ and $\mathrm{IP}_{3}$ dynamics in mast cells. The model was built upon a $3 \mathrm{D}$ reconstruction of the endoplasmic reticulum (ER) geometry from electron-tomography series. This model simultaneously tracks the changes in cytoplasmic and ER $\left[\mathrm{Ca}^{2+}\right]$, includes luminal and cytoplasmic $\mathrm{Ca}^{2+}$ buffers, plasma membrane $\mathrm{Ca}^{2+}$ fluxes, SERCA, ER leakage, and type- $2 \mathrm{IP}_{3} \mathrm{R}$. A unique feature of the model is the inclusion of the stochastic behavior of type- $2 \mathrm{IP}_{3} \mathrm{R}$. The results showed that $\mathrm{IP}_{3} \mathrm{Rs}$ in close proximity modulate the activity of their neighbors through local $\mathrm{Ca}^{2+}$ feedback effects. Finally, in 1999 an analysis performed by fluorescence measurements of $\left[\mathrm{Ca}^{2+}\right]_{\mathrm{i}}$ and $\left[\mathrm{Ca}^{2+}\right]_{\text {nuc }}$ in ventricular myocytes revealed that $\left[\mathrm{Ca}^{2+}\right]_{\text {nuc }}$ increases concomitantly with $\left[\mathrm{Ca}^{2+}\right]_{\mathrm{i}}$ upon electrical stimulation, but the pattern of $\left[\mathrm{Ca}^{2+}\right]_{\text {nuc }}$ increase was biphasic (rapid and slow) (Genka et al., 1999). Both sets of $\left[\mathrm{Ca}^{2+}\right]_{\mathrm{i}}$ and $\left[\mathrm{Ca}^{2+}\right]_{\text {nuc }}$ data were well fitted by predictions derived from a simplified model of $\mathrm{Ca}^{2+}$ diffusion across the NPCs with two different $\mathrm{Ca}^{2+}$ diffusion constants. A plausible explanation of this finding is that the change in $\left[\mathrm{Ca}^{2+}\right]_{\text {nuc }}$ is caused by $\mathrm{Ca}^{2+}$ diffusion from the cytosol to the nucleus through NPCs, but the permeability of the NPCs shifts from free to moderately restricted during contraction (Genka et al., 1999). The partial restriction of $\mathrm{Ca}^{2+}$ diffusion into the nucleus at high $\left[\mathrm{Ca}^{2+}\right]_{i}$ may support the idea of a defense mechanism protecting the nucleus against $\mathrm{Ca}^{2+}$ overload during cell contraction.

Taken together, the aforementioned modeling efforts fill a number of specific gaps of knowledge with respect to cell electrophysiology and cytosolic $\mathrm{Ca}^{2+}$ and $\mathrm{IP}_{3}$ signaling. To date, however, no quantitative model coupling the cell electrophysiology with $\mathrm{Ca}^{2+}$ and $\mathrm{IP}_{3}$ signaling in the cytosol and nucleus in cardiomyocytes exists. The development of a new system model, coupling ECC and ETC is important because: (a) this tool would provide fundamental new information on the role of $\mathrm{IP}_{3} \mathrm{R}$ mediated $\mathrm{Ca}^{2+}$ signaling during ECC for arrhythmogenesis, for electrophysiological changes and for nuclear $\mathrm{Ca}^{2+}$ signaling in normal and failing cardiac cells; (b) as more experimental details on the complexity of $\mathrm{IP}_{3}$ regulation in myocytes accumulates, the intuitive interpretation of new findings becomes increasingly impractical and sometimes controversial. In pursuing this goal we extended the Shannon-Bers model in rabbit ventricular myocytes (Shannon et al., 2004). New equations, describing nuclear $\mathrm{Ca}^{2+}$ dynamics and its dependence on $[\mathrm{Ca}]_{\mathrm{i}}$, nuclear $\mathrm{Ca}^{2+}$ buffering and transport via NPCs and NE (i.e., SR) were incorporated (see Figure 1; Michailova et al. unpublished data). Preliminary results (Figures 3A,B) show that the model predictions are in qualitative agreement with our $\mathrm{Ca}^{2+}$ transient measurements at $0.5 \mathrm{~Hz}$ electrical stimulation (see Figure 2B) and published experimental data (Ljubojevic et al., 2011) of global cytosolic and nuclear $\mathrm{Ca}^{2+}$ transients under control conditions, i.e., in absence of activation of $\mathrm{IP}_{3}$ signaling. The predicted $\left[\mathrm{Ca}^{2+}\right]_{\mathrm{i}}$ and $\left[\mathrm{Ca}^{2+}\right]_{\text {nuc }}$ transients (and action potentials and $\left[\mathrm{Ca}^{2+}\right]_{\mathrm{SR}}$; not shown) are stable during $10 \mathrm{~min}$ stimulation at $0.5,1$, or $2 \mathrm{~Hz}$. The model mimics also the frequency-dependent increases in the diastolic $\left[\mathrm{Ca}^{2+}\right]_{\mathrm{i}}$ (Shannon et al., 2004), but no obvious differences in diastolic levels of $\left[\mathrm{Ca}^{2+}\right]_{\text {nuc }}$ vs. $\left[\mathrm{Ca}^{2+}\right]_{i}$ at any given frequency were predicted. At each frequency the systolic $\mathrm{Ca}^{2+}$ peaks were lower in the nuclei and positive force-frequency increases in systolic $\left[\mathrm{Ca}^{2+}\right]_{\mathrm{i}}$ and $\left[\mathrm{Ca}^{2+}\right]_{\text {nuc }}$ were predicted. The kinetic parameters of $\mathrm{Ca}^{2+}$ transients (time to peak and time to $50 \%\left[\mathrm{Ca}^{2+}\right]$ relaxation; $\mathrm{RT}_{50}$ ) were slower in the nucleus as compared to the cytosol. The physiological utility of the model was tested further by applying different frequencies to simulate the positive force-frequency relationship (Figure 3C). In agreement with experiments (Ljubojevic et al., 2011), upon increasing the rate from 0.5 to $2 \mathrm{~Hz}$ diastolic $\left[\mathrm{Ca}^{2+}\right]$ and systolic $\mathrm{Ca}^{2+}$ peaks in the nucleus and cytoplasm increased in magnitude and the predicted amplitude of the $\mathrm{Ca}^{2+}$ transients were smaller in the nucleus compared to the cytosol.

\section{CONCLUSIONS AND FUTURE PERSPECTIVES}

In this review we discussed the current state of experimental and modeling approaches to investigate nuclear and cytosolic $\mathrm{Ca}^{2+}$ homeostasis, whereby we focused on $\mathrm{IP}_{3}$-dependent $\mathrm{Ca}^{2+}$ signaling in adult myocytes. We presented experimental data from ventricular and atrial cells, showing the effects of sudden increases in $\left[\mathrm{IP}_{3}\right]$ on nuclear and cytosolic $\mathrm{Ca}^{2+}$ transients during field stimulation as well as different approaches to study $\mathrm{IP}_{3}$-mediated $\mathrm{Ca}^{2+}$ release (i.e., FIRE-1-cyt as a tool to quantify $\left[\mathrm{IP}_{3}\right], \mathrm{IP}_{3}$ uncaging to mimic physiological increases in $\left[\mathrm{IP}_{3}\right]$ and 2 -APB to block $\mathrm{IP}_{3} \mathrm{R}$ mediated $\mathrm{Ca}^{2+}$ release). Moreover we compared experimentally the influence of $\mathrm{IP}_{3}$ uncaging on different compartments (nucleoplasm, cytosol) and were able to show that ventricular cells need a stronger $\mathrm{IP}_{3}$ stimulus to elicit a nuclear response, whereas atrial cells display substantial increases in nuclear and cytosolic $\mathrm{Ca}^{2+}$ transient amplitude upon a weaker $\mathrm{IP}_{3}$ uncaging stimulus, consistent with their higher total expression of $\mathrm{IP}_{3} \mathrm{Rs}$ as compared to ventricle. The recent development of FRET-based 

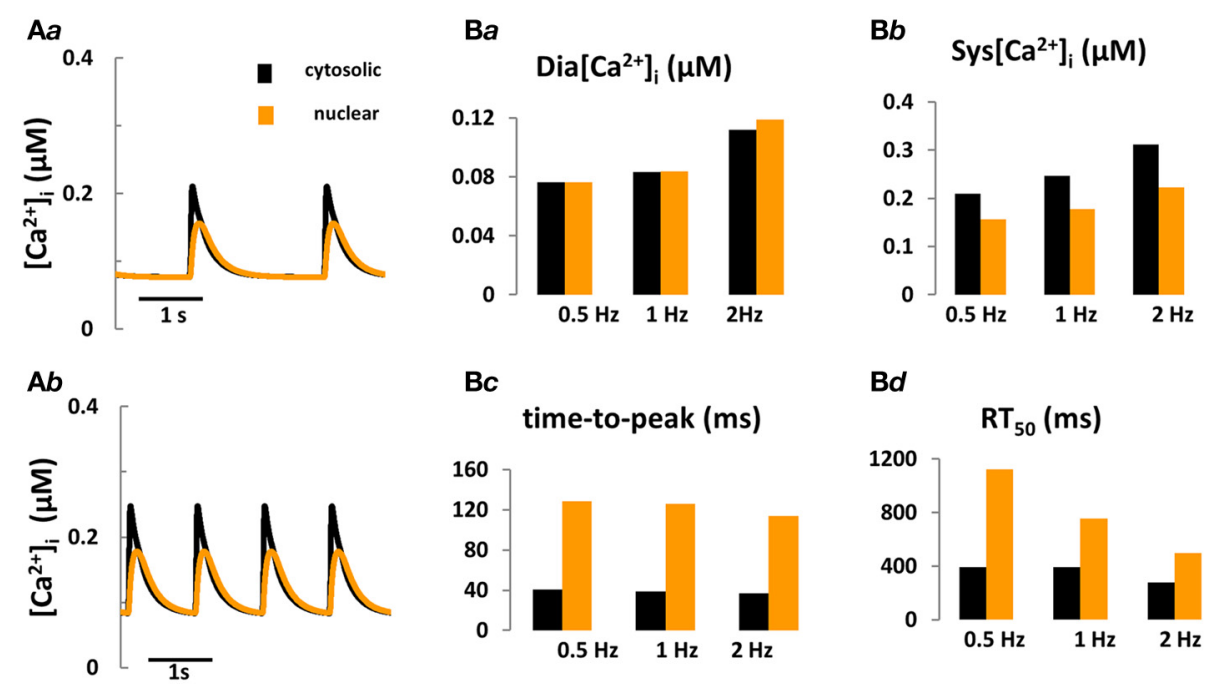

Bd
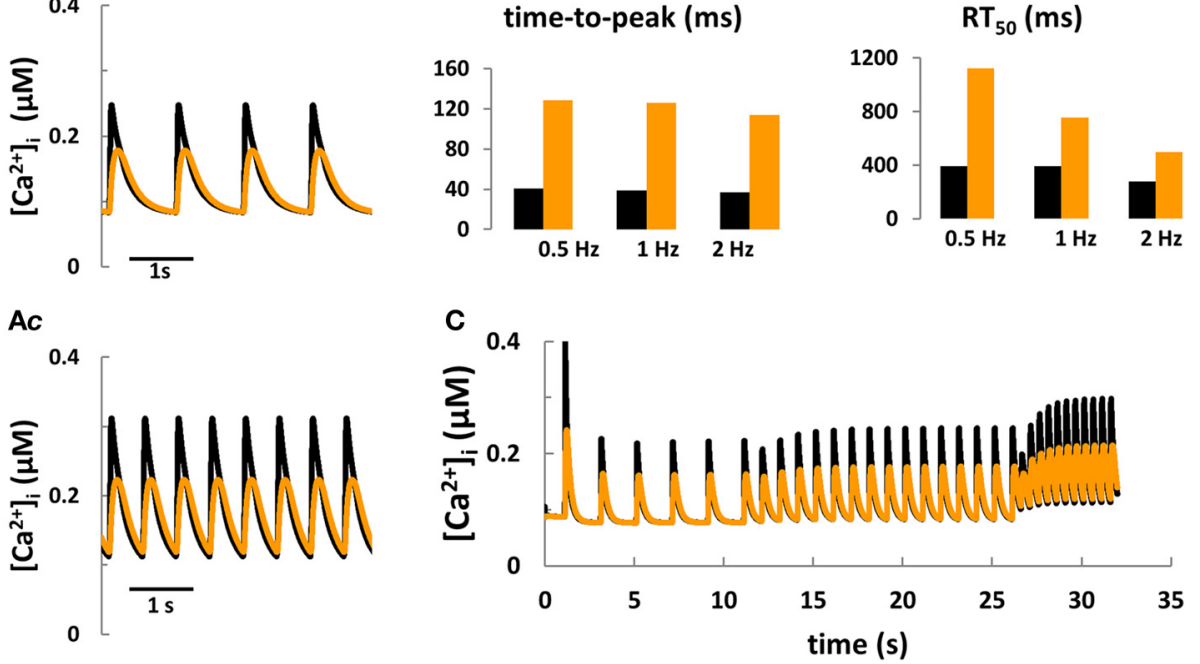

FIGURE 3 | Computer modeling of cytosolic and nuclear $\mathrm{Ca}^{2+}$ signals under control conditions. (Aa-Ac) Predicted cytosolic and nuclear steady-state $\mathrm{Ca}^{2+}$ transients under control conditions in rabbit ventricular myocytes stimulated for $10 \mathrm{~min}$ at frequencies of $0.5,1$, and $2 \mathrm{~Hz}$, respectively. (Ba-Bd) Predicted kinetic parameters of
$\left[\mathrm{Ca}^{2+}\right]_{i}$ and $\left[\mathrm{Ca}^{2+}\right]_{\text {nuc }}$ transients: Dia $\left[\mathrm{Ca}^{2+}\right]$, diastolic $\mathrm{Ca}^{2+}$; Sys $\left[\mathrm{Ca}^{2+}\right]$, systolic $\mathrm{Ca}^{2+} ; \mathrm{RT}_{50}$, time to $50 \%\left[\mathrm{Ca}^{2+}\right]$ relaxation. (C) Frequency-dependent changes in $\left[\mathrm{Ca}^{2+}\right]$ in the nucleus vs. the cytoplasm during stepwise increases of the stimulation frequency from 0.5 to $2 \mathrm{~Hz}$. probes used for the detection of $\left[\mathrm{IP}_{3}\right]$ as well as approaches to alter nuclear and/or cytosolic $\left[\mathrm{IP}_{3}\right]$ provide experimental tools for the study of $\mathrm{IP}_{3}$-dependent $\mathrm{Ca}^{2+}$ release and its importance in ECC and ETC.

We also presented our recent efforts of a first attempt to develop an electrophysiological and $\mathrm{Ca}^{2+}$ signaling model that integrates three different cellular subsystems (cytosol, SR, nucleus) and couples $\mathrm{Ca}^{2+}$ dynamics in the cytosol and nucleus. This new tool is under development and will undergo further testing in its prediction of experimental $\left[\mathrm{Ca}^{2+}\right]_{\text {nuc }}$ and $\left[\mathrm{Ca}^{2+}\right]_{\mathrm{i}}$ data in rabbit ventricular cells. The proposed model will also be extended to investigate how the complex dynamics of type-2 $\mathrm{IP}_{3}$ receptors (Sneyd and Dufour, 2002; Siekmann et al., 2012), the stochastic behavior of $\mathrm{IP}_{3} \mathrm{R}$ channel (Fraiman and Dawson, 2004) and/or the stimulation of $\mathrm{IP}_{3}$ signal transduction pathway with neurohumoral agonists (Cooling et al., 2007) regulate ventricular ECC and ETC. Furthermore, the mechanisms underlying $\mathrm{IP}_{3}$-induced positive inotropy in cardiomyocytes continue to be controversial with numerous cellular targets being implicated in the response, including $\mathrm{L}$-type $\mathrm{Ca}^{2+}$ channels, $\mathrm{K}^{+}$channels, and $\mathrm{Na}^{+} / \mathrm{Ca}^{2+}$ exchange (Lauer et al., 1992; Watanabe and Endoh, 1999; Woo and Lee, 1999; Yang et al., 1999; He et al., 2000;
James et al., 2001; Zhang et al., 2001; Puglisi et al., 2011; Signore et al., 2013). The current model can be extended to investigate these effects as well. This model also provides a good quantitative framework to integrate reactions for calmodulin (CaM), calcineurin (CaN), CaMKII, and CaM buffering in the nucleus and can be coupled to the previously described and validated ECC models of CaM-CaMKII-CaN in rabbit ventricular cells (Hund and Rudy, 2004; Grandi et al., 2007; Saucerman and Bers, 2008; Bers and Grandi, 2009; Kraeuter et al., 2010; Soltis and Saucerman, 2010). This will allow testing hypotheses on how the interactions between $\mathrm{Ca}^{2+}, \mathrm{IP}_{3}$, and CaMKII signaling pathways contribute to heart failure phenotypes. Finally, the tools and insights our group develops will be useful to investigate how perturbations in cytosolic and nuclear $\mathrm{Ca}^{2+}$ and $\mathrm{IP}_{3}$ signaling affect ECC and ETC in atrial myocytes (Grandi et al., 2011; Koivumäki et al., 2011).

\section{AUTHOR AND CONTRIBUTORS}

Designed the work: Anushka P. Michailova and Felix Hohendanner. Performed the experiments: Felix Hohendanner and Lothar A. Blatter. Performed the simulations: Anushka P. Michailova. Analyzed the data: Anushka P. Michailova, Felix 
Hohendanner, Lothar A. Blatter, and Andrew D. McCulloch. Contributed reagents/materials/analysis tools: Anushka P. Michailova, Felix Hohendanner, and Lothar A. Blatter. Wrote the paper: Anushka P. Michailova, Felix Hohendanner, Lothar A. Blatter, and Andrew D. McCulloch.

\section{ACKNOWLEDGMENTS}

This work is supported by NIBIB 1R03EB014593-01 (Michailova), National Biomedical Computational Resource (NIH grant 8P41 GM103426-19), NHLBI Systems Biology Collaboration 1R01HL105242-01 (McCulloch), and National Institutes of Health grants HL62231, HL80101 and HL101235 and the Leducq Foundation (Blatter).

\section{REFERENCES}

Alonso, M. T., and García-Sancho, J. (2011). Nuclear $\mathrm{Ca}(2+)$ signalling. Cell Calcium 49, 280-289. doi: 10.1016/j.ceca.2010.11.004

Arantes, L. A., Aguiar, C. J., Amaya, M. J., Figueiró, N. C., Andrade, L. M., Rocha-Resende, C., et al. (2012). Nuclear inositol 1,4,5-trisphosphate is a necessary and conserved signal for the induction of both pathological and physiological cardiomyocyte hypertrophy. J. Mol. Cell. Cardiol. 53, 475-486. doi: 10.1016/j.yjmcc.2012.06.017

Bare, D. J., Kettlun, C. S., Liang, M., Bers, D. M., and Mignery, G. A. (2005). Cardiac type 2 inositol 1,4,5-triphosphate receptor: interaction and modulation by calcium/calmodulin-dependent protein kinase II. J. Biol. Chem. 280, 15912-15920. doi: 10.1074/jbc.M414212200

Berridge, M. J. (2009). Inositol trisphosphate and calcium signaling mechanisms. Biochem. Biophys. Acta 1793, 933-940. doi: 10.1016/j.bbamcr.2008.10.005

Bers, D. (2001). Excitation-Contraction Coupling and Cardiac Contractile Force. Dortrecht; Boston, MA; London: Kluwer Academic Publishers. doi: 10.1007/978-94-010-0658-3

Bers, D. (2013). Membrane receptor neighborhoods: snuggling up to the nucleus. Circ. Res. 112, 224-226. doi: 10.1161/CIRCRESAHA.112.300494

Bers, D. M., and Grandi, E. (2009). CaMKII regulation of cardiac ion channels. J. Cardiovasc. Pharmacol. 54, 180-187. doi: 10.1097/FJC.0b013e3181a25078

Bkaily, G., Avedanian, L., Al-Khoury, J., Provost, C., Nader, M., D’Orléans-Juste, P., et al. (2011). Nuclear membrane receptors for ET-1 in cardiovascular function. Am. J. Physiol. Regul. Integr. Comp. Physiol., 300, R251-R263. doi 10.1152/ajpregu.00736.2009

Bkaily, G., Nader, M., Avedanian, L., Choufani, S., Jacques, D., D’Orléans-Juste, P., et al. (2006). G-protein-coupled receptors, channels, and $\mathrm{Na}+-\mathrm{H}+$ exchanger in nuclear membranes of heart, hepatic, vascular endothelial, and smooth muscle cells. J. Can. Physiol. Pharmacol. 84, 431-441. doi: 10.1139/y06-002

Blatter, L. A., Kockskamper, J., Sheehan, K. A., Zima, A. V., Huser, J., and Lipsius, S. (2003). Local calcium gradients during excitation-contraction coupling and alternans in atrial myocytes. J. Physiol. 546, 19-31. doi: 10.1113/jphysiol.2002.025239

Bootman, M. D., Fearnley, C., Smyrnias, I., MacDonald, F., and Roderick, J. L. (2009). An update on nuclear calcium signaling. J. Cell Sci. 122, 2337-2350. doi: $10.1242 /$ jcs. 028100

Cooling, M., Hunter, P., and Crampin, E. (2007). Modeling hypertrophic IP3 transients in the cardiac myocyte. Biophys. J. 93, 3421-3433. doi: 10.1529/biophysj.107.110031

Crossman, D. J., Ruygrok, P. N., Soeller, C., and Cannell, M. B. (2011). Changes in the organization of excitation-contraction coupling structures in failing human heart. PLOS ONE 6:e17901. doi: 10.1371/journal.pone.0017901

Dawson, A. P., Lea, E. J., and Irvine, R. F. (2003). Kinetic model of inositol triphosphate receptor that shows both steady-state and quantal patterns of $\mathrm{Ca}^{2+}$ release from intracellular stores. Biochem. J. 370, 621-629. doi: 10.1042/BJ20021289

De Young, G. W., and Keizer, J. (1992). A single-pool inositol 1,4,5-triphosphate receptor-based model for agonist-simulated oscillations in $\mathrm{Ca}^{2+}$ concentration. Proc. Natl. Acad. Sci. U.S.A. 89, 9895-9899. doi: 10.1073/pnas.89.20.9895

Dibb, K. M., Clarke, J. D., Horn, M. A., Richards, M. A., Graham, H. K., Eisner, D. A., et al. (2009). Characterization of an extensive transverse tubular network in sheep atrial myocytes and its depletion in heart failure. Circ. Heart Fail. 2, 482-489. doi: 10.1161/CIRCHEARTFAILURE.109.852228
Domeier, T. L., Zima, A. V., Maxwell, J. T., Huke, S., Mignery, G. A., and Blatter, L. A. (2008). $\mathrm{IP}_{3}$ receptor-dependent $\mathrm{Ca}^{2+}$ release modulates excitationcontraction coupling in rabbit ventricular myocytes. Am. J. Physiol. Heart Circ. Physiol. 294, H596-H604. doi: 10.1152/ajpheart.01155.2007

Falcke, M. (2003). On the role of stochastic channel behavior in intracellular dynamics. Biophys. J. 84, 42-56. doi: 10.1016/S0006-3495(03)74831-0

Fraiman, D., and Dawson, S. P. (2004). A model of the $\mathrm{IP}_{3}$ receptor with a luminal calcium binding site: stochastic simulations and analysis. Cell Calcium 35, 403-413. doi: 10.1016/j.ceca.2003.10.004

Franzini-Armstrong, C., Protasi, F., and Ramesh, V. (1999). Shape, size, and distribution of $\mathrm{Ca}(2+)$ release units and couplons in skeletal and cardiac muscles. Biophys. J. 77, 1528-1539. doi: 10.1016/S0006-3495(99)77000-1

Genka, C., Ishida, H., Ichimori, K., Hirota, Y., Tanaami, T., and Nakazawa, H. (1999). Visualization of biphasic Ca2 + diffusion from cytosol to nucleus in contracting adult rat cardiac myocytes with an ultra-fast confocal imaging system. Cell Calcium 25, 199-208. doi: 10.1054/ceca.1999.0026

Gerasimenko, J. V., Maruyama, Y., Yano, K., Dolman, N. J., Tepikin, A. V., Petersen, O. H., et al. (2003). NAADP mobilizes $\mathrm{Ca}^{2+}$ from a thapsigargin-sensitive store in the nuclear envelope by activating ryanodine receptors. J. Cell Biol. 163, 271-282. doi: $10.1083 /$ jcb.200306134

Gin, E., Falcke, M., Wagner, L. E. 2nd., Yule, D. I., and Sneyd, J. (2009). A kinetic model of the inositol triphosphate receptor based of single-channel data. Biophys. J. 96, 4053-4062. doi: 10.1016/j.bpj.2008.12.3964

Grandi, E., Pandit, S. V., Voigt, N., Workman, A. J., Dobrev, D., Jalife, J., et al. (2011). Human atrial action potential and Ca2+ model: sinus rhythm and chronic atrial fibrillation. Circ. Res. 109, 1055-1066. doi: 10.1161/CIRCRESAHA.111.253955

Grandi, E., Puglisi, J. L., Wagner, S., Maier, L. S., Severi, S., and Bers, D. M. (2007). Simulation of Ca-calmodulin-dependent protein kinase II on rabbit ventricular myocyte ion currents and action potential. Biophys. J. 93, 3835-3847. doi: 10.1529/biophysj.107.114868

Grynkiewicz, G., Poenie, M., and Tsien, R. Y. (1985). A new generation of Ca2+ indicators with greatly improved fluorescence properties. J. Biol. Chem. 260, 3440-3450.

Guatimosim, S., Amaya, M. J., Guerra, M. T., Aguiar, C. J., Goes, A. M., GómezViquez, N. L., et al. (2008). Nuclear Ca2+ regulates cardiomyocyte function. Cell Calcium 44, 230-242. doi: 10.1016/j.ceca.2007.11.016

Hake, J. E., Edwards, A. G., Yu, Z., Kekenes-Huskey, P., Michailova, A. P., McCammon, A., et al. (2012). Modeling cardiac calcium sparks in a threedimensional reconstruction of a calcium release unit. J. Physiol. 590, 4403-4422. doi: 10.1113/jphysiol.2012.227926

Harzheim, D., Movassagh, M., Foo, R., Ritter, O., Tashfeen, A., Conway, S. J., et al. (2009). Increased Ins $P_{3} R s$ in the junctional sarcoplasmic reticulum augment $\mathrm{Ca}^{2+}$ transients and arrhythmias associated with cardiac hypertrophy. Proc. Natl. Acad. Sci. U.S.A. 106, 11406-11411. doi: 10.1073/pnas.0905485106

He, J. Q., Pi, Y., Walker, J. W., and Kamp, T. J. (2000). Endothelin-1 and photoreleased diacylglycerol increse L-type $\mathrm{Ca}^{2+}$ current by activation of protein kinase C in rat ventricular myocytes. J. Physiol. 524, 807-820. doi: 10.1111/j.14697793.2000.00807.x

Heinzel, F. R., Bito, V., Volders, P. G., Antoons, G., Mubagwa, K., and Sipido, K. R. (2002). Spatial and temporal inhomogeneities during $\mathrm{Ca} 2+$ release from the sarcoplasmic reticulum in pig ventricular myocytes. Circ. Res. 91, 1023-1030. doi: 10.1161/01.RES.0000045940.67060.DD

Hund, T. J., and Rudy, Y. (2004). Rate dependence and regulation of action potential and calcium transient in a canine cardiac ventricular cell model. Circulation 110, 3168-3174. doi: 10.1161/01.CIR.0000147231.69595.D3

Hüser, J., Lipsius, S. L., and Blatter, L. A. (1996). Calcium gradients during excitation-contraction coupling in cat atrial myocytes. J. Physiol. 494, 641-651.

Ibarra, C. C., Vicencio, J. M., Estrada, M., Lin, Y., Rocco, P., Rebellato, P., et al. (2013). Local control of nuclear calcium signaling in cardiac myocytes by perinuclear microdomains of sarcolemmal insulin-like growth factor 1 receptors. Circ. Res. 112, 236-245. doi: 10.1161/CIRCRESAHA.112.273839

Irvine, R. F. (2003). Nuclear lipid signaling. Nat. Rev. Mol. Cell Biol. 4, 349-360. doi: $10.1038 / \mathrm{nrm} 1100$

Jafri, M. S. (2012). Models of excitation-contraction coupling in cardiac ventricular myocytes. Methods Mol. Biol. 910, 309-335. doi: 10.1007/978-1-61779-965-5_14

Jafri, M. S., and Keizer, J. (1994). Diffusion of inositol 1,4,5-triphosphate but not $\mathrm{Ca}^{2+}$ is necessary for class of inositol 1,4,5-triphosphate-iduced $\mathrm{Ca}^{2+}$ waves. Proc. Natl. Acad. Sci. U.S.A. 91, 9485-9489. doi: 10.1073/pnas.91.20.9485 
Jafri, M. S., and Keizer, J. (1995). On the roles of $\mathrm{Ca}^{2+}$ diffusion, $\mathrm{Ca}^{2+}$ buffers, and the endoplasmic reticulum in $\mathrm{IP}_{3}$-induced $\mathrm{Ca}^{2+}$ waves. Biophys. J. 69, 2139-2153. doi: 10.1016/S0006-3495(95)80088-3

James, A. F., Ramsey, J. E., Reynolds, A. M., Hendry, B. M., and Shattock, M. J. (2001). Effects of endothelin-1 on $\mathrm{K}^{+}$currents from rat ventricular myocytes. Biochem. Biophys. Res. Commun. 284, 1048-1055. doi: 10.1006/bbrc.2001.5083

Kim, J. C., Son, M. J., Subedi, K. P., Li, Y., Ahn, J. R., and Woo, S. H. (2010). Atrial local Ca2+ signaling and inositol 1,4,5-trisphosphate receptors. Prog. Biophys. Mol. Biol. 103, 59-70. doi: 10.1016/j.pbiomolbio.2010.02.002

Kirk, M. M., Izu, L. T., Chen-Izu, Y., McCulle, S. L., Wier, W. G., Balke, C. W., et al. (2003). Role of transverse-axial tubule system in generating calcium sparks and calcium transients in rat atrial myocytes. J. Physiol. 547, 441-451. doi: 10.1113/jphysiol.2002.034355

Kockskämper, J., Sheehan, K. A., Bare, D. J., Lipsius, S. L., Mignery, G. A., and Blatter, L. A. (2001). Activation and propagation of $\mathrm{Ca}^{2+}$ release during excitation-contraction coupling in atrial myocytes. Biophys. J. 81, 2590-2595. doi: 10.1016/S0006-3495(01)75903-6

Kockskämper, J., Zima, A. V., Roderick, H. L., Pieske, B., Blatter, L. A., and Bootman, M. D. (2008). Emerging roles of inositol 1,4,5-thriphosphate signaling in cardiac myocytes. J. Mol. Cell. Cardiol. 45, 128-147. doi: 10.1016/j.yjmcc.2008.05.014

Koivumäki, J. T., Korhonen, T., and Tavi, P. (2011). Impact of sarcoplasmic reticulum calcium release on calcium dynamics and action potential morphology in human atrial myocytes: a computational study. PLoS Comp. Biol. 7:e1001067. doi: 10.1371/journal.pcbi.1001067

Kraeuter, M. J., Soltis, A. R., and Saucerman, J. (2010). Modeling cardiac $\beta$ adrenergic signaling with normalized-Hill differential equations: comparison with a biochemical model. BMC Syst. Biol. 4:157. doi: 10.1186/1752-0509-4-157

Lauer, M. R., Gunn, M. D., and Clusin, W. T. (1992). Endothelin-1 activates voltagedependent $\mathrm{Ca}^{2+}$ current by a $\mathrm{G}$ protein-dependent mechanism in rabbit cardiac myocytes. J. Physiol. 448, 729-747.

Laurent, M., and Claret, M. (1997). Single-induced $\mathrm{Ca}^{2+}$ oscillations through the regulation of the inositol 1,4,5-triphosphate-gared $\mathrm{Ca}^{2+}$ channel: an allosteric model. J. Theor. Biol. 186, 307-326. doi: 10.1006/jtbi.1996.0365

LeBeau, A. P., Yule, D. I., Groblewski, G. E., and Sneyd, J. (1999). Agonistdependent phosphorylation of 1,4,5-triphosphate receptor: a possible mechanism for agonist-specific calcium oscillations in pancreatic acinar cells. J. Gen. Physiol. 113, 851-872. doi: 10.1085/jgp.113.6.851

Ledeen, R., and Wu, G. (2007). GM1 in the nuclear envelope regulates nuclear calcium through association with a nuclear sodium-calcium exchanger J. Neurochem. Suppl. 1, 126-134. doi: 10.1111/j.1471-4159.2007.04722.x

Li, X., Zima, A. V., Sheikh, F., Blatter, L. A., and Chen, J. (2005). Endothelin1 -induced arrhythmogenic $\mathrm{Ca}^{2+}$ signaling is abolished in atrial myocytes of inositol-1,4,5-trisphosphate $\left(\mathrm{IP}_{3}\right)$-receptor type 2-deficient mice. Circ. Res. 96, 1274-1281. doi: 10.1161/01.RES.0000172556.05576.4c

Li, Y. X., and Rinzel, J. (1994). Equations for $\mathrm{InsP}_{3}$ receptor-mediated $\left[\mathrm{Ca}^{2+}\right]_{i}$ oscillations derived from a detailed kinetic model: a Hodgkin-Huxley like formalism. J. Theor. Biol. 166, 461-473. doi: 10.1006/jtbi.1994.1041

Ljubojevic, S., Walther, S., Asgarzoei, M., Sedej, S., Pieske, B., and Kockskämper, J. (2011). In situ calibration of nucleoplasmic versus cytoplasmic $\mathrm{Ca}^{2+}$ concentration in adult cardiomyocytes. Biophys. J. 100, 2356-2366. doi: 10.1016/j.bpj.2011.03.060

Louch, W. E., Bito, V., Heinzel, F. R., Macianskiene, R., Vanhaecke, J., Flameng, W., et al. (2004). Reduced synchrony of Ca2+ release with loss of T-tubules-a comparison to $\mathrm{Ca} 2+$ release in human failing cardiomyocytes. Cardiovasc. Res. 62, 63-73. doi: 10.1016/j.cardiores.2003.12.031

Mackenzie, L., Roderick, H. I., Proven, A., Conway, S. J., and Bootman, M. D. (2004). Inositol 1,4,5,-triphosphate receptors in the heart. Biol. Res. 37, 553-557. doi: 10.4067/S0716-97602004000400008

Mak, D., McBride, S., and Foskett, J. K. (2001). Regulation by $\mathrm{Ca}^{2+}$ and inositol 1,4,5-triphosphate $\left(\mathrm{InsP}_{3}\right)$ of single recombinant type $3 \mathrm{InsP}_{3}$ receptor channels: $\mathrm{Ca}^{2+}$ activation uniquely distinguishes types 1 and $3 \mathrm{InsP}_{3}$ receptors. J. Gen. Physiol. 117, 435-446. doi: 10.1085/jgp.117.5.435

Malviya, A. N., and Klein, C. (2006). Mechanism regulating nuclear calcium signaling. Can. J. Physiol. Pharmacol. 84, 403-422. doi: 10.1139/y05-130

Maxwell, J. T., and Blatter, L. A. (2012). Facilitation of cytosolic calcium wave propagation by local calcium uptake into the sarcoplasmic reticulum in cardiac myocytes. J. Physiol. 590, 6037-6045. doi: 10.1113/jphysiol.2012.239434
Means, S., Smith, A. J., Shepherd, J., Shadid, J., Fowler, J., Wojcikiewicz, R. H. J., et al. (2006). Reaction diffufion modeling of calcium dynamics with realistic ER geometry. Biophys. J. 91, 537-557. doi: 10.1529/biophysj.105.075036

Michell, R. H., Kirk, C. J., Jones, L. M., Downes, C. P., and Creba, J. A. (1981). The stimulation of inositol lipid metabolism that accompanies calcium mobilization in stimulated cells: defined characteristics and unanswered questions. Philos. Trans. R. Soc. Lond. Biol. Sci. 296, 123-138. doi: 10.1098/rstb.1981.0177

Molkentin, J. D., Lu, J. R., Antos, C. L., Markham, B., Richardson, J., Robbins, J., et al. (1998). A calcineurin-dependent transcriptional pathway for cardiac hypertrophy. Cell 93, 215-228. doi: 10.1016/S0092-8674(00)81573-1

Moraru, I., Kaftan, E. J., Ehrlich, B. E., and Watras, J. (1999). Regulation of type 1 inositol 1,4,5-triphosphate-gated calcium channels by $\mathrm{InsP}_{3}$ and calcium: simulation of single channel kinetics based on ligand binding and electro physiological analysis. J. Gen. Physiol. 113, 837-849. doi: 10.1085/jgp.113.6.837

Nakayama, H., Bodi, I., Maillet, M., DeSantiago, J., Domeier, T. L., Mikoshiba, K., et al. (2010). The $\mathrm{IP}_{3}$ receptor regulates cardiac hypertrophy in response to select stimuli. Circ. Res. 107, 659-666. doi: 10.1161/CIRCRESAHA 110.220038

Noble, D. (2011). Successes and failures in modeling heart cell electrophysiology. Heart Rhythm 8, 1798-1803. doi: 10.1016/j.hrthm.2011.06.014

Noble, D., Garny, A., and Noble, P. J. (2012). How the Hodgkin-Huxley equations inspired the cardiac physiome project. J. Physiol. 590, 2613-2628. doi: 10.1113/jphysiol.2011.224238

Petersen, O. H., Petersen, C. C., and Kasai, H. (1994). Calcium and hormone action. Annu. Rev. Physiol. 56, 297-319. doi: 10.1146/annurev.ph.56.030194.001501

Poláková, E., and Sobie, E. A. (2013). Alterations in T-tubule and dyad structure in heart disease: challenges and opportunities for computational analyses. Cardiovasc. Res. 98, 233-239. doi: 10.1093/cvr/cvt026

Proven, A., Roderick, H. L., Conway, S. J., Berridge, M. J., Horton, J. K., Capper, S. J., et al. (2006). Inositol 1,4,5,-supports the arrhythmogenic action of endothelin-1 on ventricular cardiac myocytes. J. Cell Sci. 119, 3363-3375. doi: $10.1242 /$ jcs.03073

Puglisi, J. L., Yuan, W., Timofeyev, V., Myers, R. E., Chiamvimonvat, N., Samarel, A. M., et al. (2011). Phorbol ester and endothelin-1 alter functional expression of $\mathrm{Na}+/ \mathrm{Ca} 2+$ exchange, $\mathrm{K}+$, and $\mathrm{Ca} 2+$ currents in cultured neonatal rat myocytes. Am. J. Physiol. Heart Circ. Physiol. 300, H617-H626. doi: 10.1152/ajpheart.00388.2010

Remus, T. P., Zima, A. V., Bossuyt, J., Bare, D. J., Martin, J. L., and Blatter, L. A. (2006). Biosensors to measure inositol 1,4,5-triphosphate concentration in living cells with spatiotemporal resolution. J. Biol. Chem. 281, 608-616. doi: 10.1074/jbc.M509645200

Richards, M. A., Clarke, J. D., Saravanan, P., Voigt, N., Dobrev, D., Eisner, D. A., et al. (2011). Transverse tubules are a common feature in large mammalian atrial myocytes including human. Am. J. Physiol. Heart Circ. Physiol. 301, H1996-H2005. doi: 10.1152/ajpheart.00284.2011

Roderick, H. L., and Bootman, M. D. (2003). Bi-directional signaling from the InsP3 receptor: regulation by calcium and accessory factors. Biochem. Soc. Trans. 31, 950-953. doi: 10.1042/BST0310950

Saucerman, J., and Bers, D. M. (2008). Calmodulin mediates differential sensitivity of CaMKII and calcineurin to local $\mathrm{Ca}^{2+}$ in cardiac myocytes. Biophys. J. 95, 4597-4612. doi: 10.1529/biophysj.108.128728

Shannon, T., Wang, F., Puglisi, J., Weber, C. H. R., and Bers, D. B. (2004). A mathematical treatment of integrated $\mathrm{Ca}$ dynamic within the ventricular myocyte. Biophys. J. 87, 3351-3371. doi: 10.1529/biophysj. 104.047449

Shkryl, V. M., Maxwell, J. T., and Blatter, L. A. (2012). A novel method for spatially complex diffraction-limited photoactivation and photobleaching in living cells. J. Physiol. 590, 1093-1100. doi: 10.1113/jphysiol.2011.223446

Shuai, J. W., and Jung, P. (2002). Stochastic properties of $\mathrm{Ca}^{2+}$ release of inositol 1,4,5-trisphosphate receptor clusters. Biophys. J. 83, 87-97. doi: 10.1016/S00063495(02)75151-5

Siekmann, I., Wagner, L. E. 2nd., Yule, D., Crampin, E. J., and Sneyd, J. (2012). A kinetic model for type I and II IP3R accounting for mode changes. Biophys. J. 103, 658-668. doi: 10.1016/j.bpj.2012.07.016

Signore, S., Sorrentino, A., Ferreira-Martins, J., Kannappan, R., Shafaie, M., Del Ben, F., et al. (2013). Inositol 1, 4, 5-trisphosphate receptors and human left ventricular myocytes. Circulation 128, 1286-1297. doi: 10.1161/CIRCULATIONAHA.113.002764 
Smith, I. F., Wiltgen, S. M., and Parker, I. (2009). Localization of puff sites adjacent to the plasma membrane: functional and spatial characterization of $\mathrm{Ca} 2+$ signaling in SH-SY5Y cells utilizing membrane-permeant caged IP3. Cell Calcium 45, 65-76. doi: 10.1016/j.ceca.2008.06.001

Sneyd, J., and Dufour, J. F. (2002). A dynamic model of the type-2 inositol triphosphate receptor. Proc. Natl. Acad. Sci. U.S.A. 99, 2398-2403. doi: 10.1073/pnas.032281999

Sobie, E. A., and Lederer, W. J. (2012). Dynamic local changes in sarcoplasmic reticulum calcium: physiological and pathophysiological roles. J. Mol. Cell. Cardiol. 52, 304-311. doi: 10.1016/j.yjmcc.2011.06.024

Soltis, A. R., and Saucerman, J. (2010). Synergy between CaMKII substrates and $\beta$ adrenergic signaling in regulation of cardiac myocyte $\mathrm{Ca}^{2+}$ handling. Biophys. J. 99, 2038-2047. doi: 10.1016/j.bpj.2010.08.016

Swillens, S., Champeil, P., Combettes, L., and Dupont, G. (1998). Stochastic simulation of a single inositol 1,4,5-trisphosphate-sensitive Ca2+ channel reveals repetitive openings during 'blip-like' Ca2+ transients. Cell Calcium 23, 291-302. doi: 10.1016/S0143-4160(98)90025-2

Tadevosyan, A., Vaniotis, G., Allen, B. G., Hebert, T. E., and Nattel, S. (2012). G protein-coupled receptor signalling in the cardiac nuclear membrane: evidence and possible roles in physiological and pathophysiological function. J. Physiol. 590, 1313-1330. doi: 10.1113/jphysiol.2011.222794

Takahashi, A., Camacho, P., Lechleiter, J. D., and Herman, B. (1999). Measurement of intracellular calcium. Physiol. Rev. 79, 1089-1125.

Thul, R., and Falcke, M. (2004). Release currents of $\mathrm{IP}_{3}$ receptor channel clusters and concentration profiles. Biophys. J. 86, 2660-2673. doi: 10.1016/S00063495(04)74322-2

Vaniotis, G., Allen, B. G., and Hebert, T. E. (2011). Nuclear GPCRs in cardiomyocytes: an insider's view of beta-adrenergic receptor signaling. Am. J. Physiol. Heart Circ. Physiol. 301, H1754-H1764. doi: 10.1152/ajpheart.00657.2011

Vogelsand, M., Broede-Sitz, A., Schafer, E., Zerkowski, H. R., and Brodde, O. E. (1994). Endothelin $\mathrm{ET}_{A}$-receptors couple to inositol phosphate formation and inhibition of adenylate cyclase in human right atrium. J. Cardiovasc. Pharmacol. 23, 344-347. doi: 10.1097/00005344-199402000-00025

Wang, H., and Clapham, D. E. (1999). Conformational changes of the in situ nuclear pore complex. Biophys. J. 77, 241-247. doi: 10.1016/S00063495(99)76885-2

Watanabe, T., and Endoh, M. (1999). Characterization of the endothelin-1 induced regulation of L-type $\mathrm{Ca}^{2+}$ current in rabbit ventricular myocytes. Naunyn Schmiedebergs Arch. Pharmacol. 360, 654-664. doi: 10.1007/s002109900130

Wilhelms, M., Hettmann, H., Maleckar, M. M., Koivumäki, J. T., Dössel, O., and Seemann, G. (2013). Benchmarking electrophysiological models of human atrial myocytes. Front. Physiol. 3:487. doi: 10.3389/fphys.2012.00487

Woo, S. H., and Lee, C. (1999). Effects of endothelin-1 on $\mathrm{Ca}^{2+}$ signaling in guineapig ventricular myocytes: role of protein kinase C. J. Mol. Cell. Cardiol. 31, 613-643. doi: 10.1006/jmcc.1998.0899

Woodcock, E. A., and Matkovich, S. J. (2005). Ins(1,4,5)P3 receptors and inositol phosphates in the heart-evolutionary artefacts or active signal transducers? Pharmacol. Ther. 107, 240-251. doi: 10.1016/j.pharmthera. 2005.04.002

Wu, G., Xie, X., Lu, Z. H., and Ledeen, R. W. (2009). Sodium-calcium exchanger complexed with GM1 ganglioside in nuclear membrane transfers calcium from nucleoplasm to endoplasmic reticulum. Proc. Natl. Acad. Sci. U.S.A. 106, 10829-10834. doi: 10.1073/pnas. 0903408106

Wu, X., Zhang, T., Bossuyt, J., Li, X., McKinsey, T. A., Dedman, J. R., et al. (2006). Local Ins $\mathrm{P}_{3}$-dependent perinuclear $\mathrm{Ca}^{2+}$ signaling in cardiac myocyte excitation-transcription coupling. J. Clin. Invest. 116, 657-682. doi: 10.1172/JCI27374

Yang, H. T., Sakurai, K., Sugawara, H., Watanabe, T., Norota, I., and Endoh. M. (1999). Role of $\mathrm{Na}^{+} / \mathrm{Ca}^{2+}$ exchange in endothelin-1-induced increases in $\mathrm{Ca}^{2+}$ transient and contractility in rabbit ventricular myocytes: pharmacological analysis with KB-R7943. Br. J. Pharmacol. 126, 1785-1795. doi: 10.1038/sj.bjp.0702454

Youm, J. B., Kim, N., Han, J., Kim, E., Joo, H., Leem, C. H., et al. (2006). A mathematical model of pacemaker activity recorded from mouse small intestine. Philos. Trans. A Math. Phys. Eng. Sci. 364, 1135-1154. doi: 10.1098/rsta.2006.1759

Zhang, Y. H., James, A. F., and Hancox, J. C. (2001). Regulation by endothelin1 of $\mathrm{Na}^{+}-\mathrm{Ca}^{2+}$ exchange current $\left(\mathrm{I}_{\mathrm{NaCa}}\right)$ from guinea-pig isolated ventricular myocytes. Cell Calcium 30, 351-360. doi: 10.1054/ceca.2001.0244

Zima, A. V., Bare, D. J., Mignery, G. A., and Blatter, L. A. (2007). IP 3 -dependent nuclear $\mathrm{Ca}^{2+}$ signaling in the mammalian heart. J. Physiol. 584, 601-611. doi: 10.1113/jphysiol.2007.140731

Zima, A. V., and Blatter, L. A. (2004). Inositol 1,4,5-triphosphate-dependent $\mathrm{Ca}^{2+}$ signaling in cat atrial excitation-contraction coupling and arrhythmias. J. Physiol. 555, 607-615. doi: 10.1113/jphysiol.2003.058529

Conflict of Interest Statement: The authors declare that the research was conducted in the absence of any commercial or financial relationships that could be construed as a potential conflict of interest.

Received: 18 December 2013; accepted: 18 February 2014; published online: 06 March 2014.

Citation: Hohendanner F, McCulloch AD, Blatter LA and Michailova AP (2014) Calcium and IP3 dynamics in cardiac myocytes: experimental and computational perspectives and approaches. Front. Pharmacol. 5:35. doi: 10.3389/fphar.2014.00035

This article was submitted to Pharmacology of Ion Channels and Channelopathies, a section of the journal Frontiers in Pharmacology.

Copyright (C) 2014 Hohendanner, McCulloch, Blatter and Michailova. This is an open-access article distributed under the terms of the Creative Commons Attribution License (CC BY). The use, distribution or reproduction in other forums is permitted, provided the original author(s) or licensor are credited and that the original publication in this journal is cited, in accordance with accepted academic practice. No use distribution or reproduction is permitted which does not comply with these terms. 